\title{
Foundations of a Marxist Theory of the Political Economy of Information: Trade Secrets and Intellectual Property, and the Production of Relative Surplus Value and the Extraction of Rent-Tribute
}

\author{
Jakob Rigi \\ Central European University, Budapest, Hungary, rigij@ceu.hu
}

\begin{abstract}
The aim of this article is to sketch a preliminary outline of a Marxist theory of the political economy of information. It defines information as a symbolic form that can be digitally copied. This definition is purely formal and disregards epistemological, ideological, and functional aspects. The article argues that the value of information defined in this sense tends to zero and therefore the price of information is rent. However, information plays a central role in the production of relative surplus value on the one hand, and the distribution of the total social surplus value in forms of surplus profits and rents, on the other. Thus, the hegemony of information technologies in contemporary productive forces has not made Marx's theory of value irrelevant. On the contrary, the political economy of information can only be understood in the light of this theory. The article demonstrates that the capitalist production and distribution of surplus value at the global level forms the foundation of the political economy of information.
\end{abstract}

Keywords: Information, Value, Relative Surplus Value, Surplus Profit, Information Rent

Acknowledgement: A constant dialogue with Robert Prey since we met in the summer of 2012 has enriched my understanding of information rent. He has also edited the text of this article. Participation in conferences organized by Christian Fuchs and discussions with him have helped me to develop my own understanding of the political economy of information. Two reviewers of triple $C$ made thorough and careful critiques of an earlier version of this article. Dealing with the questions they had raised I decided to divide the initial article into three articles, the first of which appears here. I am grateful to all these individuals. However, needless to say, I am alone responsible for all shortcomings.

\section{Introduction}

This article attempts to sketch the outline of a Marxist theory of the political economy of information. Information in this context is defined as forms of perception or cognition such as codes, concepts, formulas, data, design, images, software, language, etc., that can be digitally and infinitely reproduced. Information is universal commons, unless it is enclosed by trade secret or intellectual property. ${ }^{1}$ Information is defined here formally regardless of its relation to truth and the purposes it is used for. Thus, in this context, deceptive ideological forms and even outright lies qualify as information. In this sense, information includes a wide range of symbolic forms, such as critical theory and natural sciences on the one hand, and the most vain and banal forms of advertisement and misleading PR propaganda on the other.

In both business studies and the information science, data, information, and knowledge are distinguished from each other according to the level of understanding each conveys (Bostol and Canals 2014; Frost 2013/2010; Zin 2007). ${ }^{2}$ The following definitions by Donald Hawkins illustrate this:

Data are facts and statistics that can be quantified, measured counted and stored. Information is data that has been categorized, counted, and this gives meaning, relevance or

\footnotetext{
${ }^{1}$ Commons of information, related forms of intellectual property, and common-based peer production are the subjects of another article, which is a sequel to this article. It will also appear in tripleC.

${ }^{2}$ I am grateful to Robert Prey for bringing this distinction to my attention.
} 
purpose. Knowledge is information that has been given meaning and taken to a higher level. Knowledge emerges from analysis, reflection upon, and synthesis of information. (quoted in Zin 2007, 483).

Acknowledging the significance and epistemological subtleties and difficulties of such a distinction (Zin 2007) I am not concerned with it in this article. Here, I intentionally lump together data, information, and formal knowledge into, in the absence of a better term, a broader concept of information. This move is legitimate because I am only concerned with political economy of these three forms and not their epistemological statuses. From the point of view of Marx's labour theory of value, what matters, as it will be shown in this article, is that all these forms can be digitally reproduced and transported at negligible cost. An important qualification is in order here. Only forms of knowledge that can be digitally copied are included in my concept of information. Thus, this concept does not cover practical knowledge (like knowledge on how to walk), tacit/intuitive knowledge that cannot be formalised (Bourdieu 1977/1972), and emotional knowledge (feelings of pain, pleasure, etc). These forms of knowledge are inseparable from the body of the individual. Thus, they cannot be formalised, or reproduced, transported and transferred digitally.

I also distinguish between the knowledge worker in general and the information worker. Knowledge workers are those workers that the processing of knowledge constitutes a major aspect of their work. Information workers consist of that section of knowledge workers who produce symbolic forms that can be digitally reproduced. A teacher uses information and produces information in giving a lecture, but the service of teaching cannot be reproduced digitally. While a lecture can be digitally recorded and reproduced, a teacher must spend new energy on delivering the same lecture to another audience. Thus, a teacher in her capacity of producing information is an information worker and in her capacity of producing the service of teaching is not an information worker. Nurses and doctors are types of knowledge workers because the processing of knowledge and information is a major aspect of their work. However, they are clearly not information workers in the terms of my definition here because the services that they produce cannot be digitally reproduced. In my definition, only those workers who exclusively produce symbolic forms that can be digitally reproduced are information workers.

As the reader might have realised, these concepts of information and information worker are closely related to information technologies. Although information has been central to all human societies, "the information technological paradigm" (ITP) (Castells 2010/1996, 69-76) is a very specific contemporary phenomenon, which is also one of the defining features of contemporary capitalism. As Castells (2010/1996, 70-72) suggests ITP is characterized by the fact that: 1) information is the raw material of these technologies; 2) these technologies permeate all aspect of contemporary life; 3 ) they are embedded in and facilitate a networking logic; and 4) various elements of these technologies such as micro-electronics, digital computing, micro-biology, etc., converge and are integrated into a highly complex system.

Currently, information technologies are a means of production for surplus value and its distribution on a global scale. The creation of a new global social division of labour, new methods of producing relative surplus value, the expansion of rent, particularly information rent, and the financialisation of the global economy, are all interconnected aspects of contemporary capitalism, which are also mediated by ITP (Mandel 1975/1972; Zeller 2008; Teixeira and Rotta 2012; Rigi and Prey [forthcoming]).

My description of contemporary capitalism, to the extent that it emphasizes the role of information technologies, overlaps with Castells' (2010/1996) concept of "the network society", and Hardt and Negri's (2000) definition of "empire". However, it profoundly differs from both by insisting that particular forms of production and distribution of surplus value are the determining features of contemporary capitalism. Castells is silent on the issue of surplus value and presents the so-called "network society" a break with industrial capitalism. Hardt and Negri's definition is based on the mistaken assumption that the law of value is not dominant anymore (Hardt and Negri 1994, 9). Webster (2006) and Fuchs (2009), among others, have questioned Castells' assumption on the total novelty of "information society". Both critiques 
emphasize that contemporary capitalism shares major characteristics with earlier forms of capitalism.

Agreeing with Fuchs and Webster, as the reader will see, I argue that the production and distribution of surplus value is the core aspect of contemporary capitalism. Thus, this paper theorises the political economy of information by describing and analysing the impacts of information on the mechanisms of production and distribution of surplus value by both individual capitals and the total social capital (Marx 1981, 241-301). The paper argues that although the value of information is almost zero, information plays central roles in the production and distribution of surplus value.

The hegemonic role of information in contemporary capitalism (Castells 2010/1996; Hardt and Negri 2000) has misled Negri and his associates to declare that the law of value does not govern contemporary "post-modern capitalism". This claim is fundamentally wrong; the laws of value and surplus value remain the basic foundations of contemporary capitalism. I do not critique this mistaken view here as I have comprehensively dealt with it elsewhere (Rigi n.d.). However, the theory of the political economy of information offered in this article exposes the weaknesses of this view.

Christian Fuchs (2010, 2012 a, b), building on Dallas Smythe (1977), has established a theory on the political economy of information which has gained increasing popularity among radical media scholars. The strength of Fuchs' approach is that he has persistently argued that the production of surplus value remains the foundation of information capitalism. Sharing this position with Fuchs, my understanding of the political economy of information, however, differs from his. He argues that information includes abstract value as defined by Marx (1976). I, on the other hand, argue that while a piece of information may have a price, its value always tends towards zero. Therefore, the price of information does not, as Fuchs claims, represent a value that is embedded in it but is instead rent. By this, however, I do not mean that information workers are not exploited. Fuchs correctly insists that information workers, whether paid or unpaid, are exploited. I qualify his argument by showing that this exploitation does not take the form of the extraction of surplus value but rather that of surplus time, and the expropriation of commons (see also: Rigi and Prey [forthcoming]). The presentation of my own understanding of the political economy of information here will exhibit to the reader-whom I expect to be familiar with Fuchs' theory-our differences.

The summary of the article is as follows. First, using Marx's definition of socially necessary abstract labour that produces value, I demonstrate that the value of information tends to zero. In the second step I show that information plays a central role in the production of relative surplus value. Then, I proceed to demonstrate that trade secrets are major instruments for the appropriation of surplus profit and rent. The fourth section analyses the role of intellectual property in the extraction of rent. It has two parts. The first part introduces the different forms of ground rent described by Marx. The second part describes various forms of information rent in light of Marx's theory of ground rent. Information rent is defined as the price that is paid for the use of information. The fifth section argues that the origin of information surplus profits and information rents is the surplus value that is produced by the totality of the global working class. For this reason, it argues, the expansion of the information economy has been an important factor behind the globalization of manufacturing and service sectors, and the related rise of neoliberalism. The sixth section describes forms of exploitation that are mediated by information. It shows that information capitalists not only exploit information workers by extracting from them surplus labour/time and enclosing commons they produce, but they also exploit all workers in the world who produce surplus value. The conclusion sketches the determinant features of contemporary capitalism in light of the arguments that are developed in this article, suggesting that the overthrow of capitalism is the immediate historical task of humanity.

\section{Value of Information}

As mentioned, according to Marx's theory of value, the value of information tends to zero. The reason for this is that information can be reproduced at almost zero cost (Teixeira and 
Rotta 2008; Perelman 2002, 2003; Zeller 2008; Rigi and Prey forthcoming). For example, if the labour time that is required for writing software is 100 hours and the time required for copying it is five minutes, its value is determined by 5 -minute labour time, which is negligible. The reason for this is that the value of a commodity is determined by the socially necessary labour time for its reproduction (Marx 1981, 522). In the case of information this time is the socially necessary time for copying it. As the copy and the original have the same use value they are the same commodity. Thus in the case of our software the 5 minute copying time determines the social labour necessary for the production of software, not the initial 100 hours spent on the production of the first original copy. Often, the time spent on copying does not even produce negligible value, because the users themselves perform the labour of copying. ${ }^{3}$ Marx expresses the idea that information has a negligible value in the two following passages:

The product of mental labour-science-always stands far below its value, because the labour-time needed to reproduce it has no relation at all to the labour-time required for its original production. For example, a schoolboy can learn the binomial theorem in an hour (Marx 1978, 353, quoted in Perelman 2003, 305).

"Once discovered, the law of the deflection of a magnetic needle in the field of an electric current, or the law of the magnetization of iron by electricity, cost absolutely nothing" (Marx 1977, 508, quoted in Perelman, ibid).

In order to prove that the labour time required for the reproduction of a commodity determines its value, we need to briefly pause and analyse the concept of socially necessary labour time that constitutes value. Consider 100 producers who produce the same pair of shoes with varying productivities, each spending respectively $T_{1}, T_{2}, \ldots T_{100}$ for producing the respective pair of shoes. The socially necessary labour time for the production of the pair of shoes is $\left(T_{1}+T_{2}+\ldots+T_{100}\right) / 100$. In other words the average social productivity of all producers determines the amount of socially necessary labour time that congeals as value in the product. In order to produce cheaper, and thereby acquire a greater share of the market, individual capitalists increase the labour productivity of their own enterprises. This in its turn leads to the growth of the average social productivity of all enterprises that produce a certain commodity. As a result the socially necessary labour time for the production of the commodity, and thereby its value, decreases. If there is a stock of a commodity previously produced under a lower labour productivity, its value depreciates. Now, it has a value as if it has been reproduced under the new higher labour productivity. As a rule, labour productivity grows in all branches of production and thereby the value embodied in a unit of any commodity decreases (Marx 1973; Rosdolsky 1966). Marx stated this clearly in the third volume of Capital.

Apart from all accidental circumstances, a large part of the existing capital is always being more or less devalued in the course of the reproduction process, since the value of commodities is determined not by the labour-time originally taken by their production, but rather by the labour-time that their reproduction takes, and this steadily decreases as the social productivity of labour develops. At a higher level of development of social productivity, therefore, all existing capital, instead of appearing as the result of a long process of capital accumulation, appears as the result of a relatively short reproduction period (1981, 522) (italics added for emphasis).

Information is a singular commodity in this respect. While the values of other commodities decrease gradually and as a result of the growth of social productivity that of a piece of information decreases immediately and infinitely in the very moment that production of its first instance is completed and this happens regardless of the general level of social productivity. The reason is that at that very moment it can be reproduced at a negligible extra cost. Therefore, although a product of labour, information's value approximates to zero. An important

\footnotetext{
${ }^{3}$ That information has no exchange value and, thus, information workers do not produce surplus value, does not imply that these workers are not exploited by capitalism. Below, we will deal with mechanisms of this exploitation.
} 
note is in order here. The non-digital reproduction of information requires the use of materials such as paper, ink, etc, and instruments, such as printing machines. While the reproduction of information itself has no extra cost, the reproduction of the material in which information is inscribed has cost, and the other conditions being equal, its cost of reproduction is equal to that of its production. In this sense a printed book has a value that consists of the value of constant capital used in its reproduction plus the value that is added by labour during the reproduction process of its material body. The author of the book, on the other hand, does not contribute at all to its value, because the reproduction of the symbolic content does not require a new input of labour. ${ }^{4}$ The particularity of the digital reproduction of information consists in that it frees information from a particular material body and, therefore, its cost tends to zero. We will return to this point when discussing the relation between copyright and rent.

Paradoxically, while the contribution of information to the total value produced in the global capitalist economy is negligible, like land, it is an indispensable foundation of this economy. Without information, as without land, any production, including that of value and surplus value will cease to exist. Information, like land, has always played a central role in the capitalist economy. First, science and technological innovations have constantly been major factors of the growth of labour productivity (Marx 1976). This growth has been a main source of surplus profit for individual capitalists on the one hand, and the main source of relative surplus value for all capitalists on the other. Second, the monopolisation of information through trade secrets and intellectual property are a means for the transfer of huge part of the world's total surplus value into surplus profits and rents, which are appropriated by the monopolisers of information. Third, information is the major base for both mass and social media and thereby also a base for the extraction of adverting rent.

Robert Prey and I (Rigi and Prey [forthcoming]) have discussed the media's revenues from advertisement elsewhere. Therefore, in this paper, I only discuss the impacts of trade secrets and commodification of information on the distribution of the total social surplus value.

Trade secret and intellectual property as major mechanisms of distribution of the total global surplus value produced by the global working class are major aspects of contemporary capitalism. Trade secrets and intellectual property are, however, two different types of monopolies and generate different types of revenues. The first generates profit or rent by being a comoponent of or a favourable condition for the production or sale of a certain commodity. The second results in rent-tribue by being directly traded as a commodity. ${ }^{5}$ For analysing these mechanisms we need a breif review of Marx theory of the distribution of the total social surplus value produced by the total social capital. ${ }^{6}$ However, before that let's explore the impact of information on the very production of surplus value.

\section{Information and the Production of Relative Surplus Value}

The origin of monetized capitalist wealth is labour (Marx 1976, 1981), though, if we consider wealth as use value, nature also contributes to it (Marx 1976). Distinguishing between labour power and labour, Marx defines the first as the capacity to perform labour, and the second as the actual labour process. Under capitalism, labour power is a commodity that is purchased and used by capitalists. The use value of labour power for capitalists is the labour that produces commodities, the value of which is higher than the value of capital used in their pro-

\footnotetext{
${ }^{4}$ From that authors' labour does not contribute to the value of their work by no means follows that authors should not be paid. Authors perform important socially useful labour, and therefore, must be compensated. However, the current regime of compensation through royalties is unfair. A handful of authors such as Stephen King become millionaires while the major can barely make a living from their works. As will be discussed below royalties are rent extracted from the value producing working class.

${ }^{5}$ David Almeling (2012) classifies trade secret as a sub-category of intellectual property, defining the latter a property that results from intellectual activity. Rebecca Blank et al (2012), on the other hand, restrict intellectual property to trademark, copyright and patent and do not include in it trade secret. I find the distinction between trade secret and intellectual property useful, because, the former is not a commodity while the second is a commodity.

${ }^{6}$ The total social capital is the aggregate of all capitals invested by individual capitalists (Marx 1981).
} 
duction. The difference is surplus value, pocketed by capitalists. Labour performs the three following services for capital: it transfers the value of means of production (constant capital) to commodities; it reproduces the value of labour power (variable capital); and it produces the surplus value (Marx 1976, chapter 7). Thus, the labour day of the worker is divided into two parts. The first part reproduces the value of labour power and the second one produces the surplus value. This can be illustrated by the following graph.

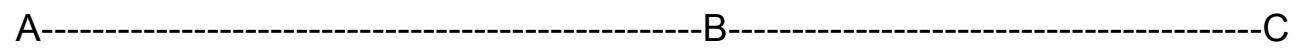

$A C$ is the labour day, $A B$ is the necessary labour time and $B C$ is the surplus labour time. $A B$ reproduces the value of labour power and $B C$ produces the surplus value. For a given $A B$ the capitalist increases the volume of surplus value by extending the $\mathrm{BC}$, which is the same as the extension of the labour day. Marx calls this the method of the production of absolute surplus value (1976). But the extension of BC has both natural and social limits (Marx 1976). Naturally, the whole time of the worker, i.e. the whole of her life, cannot be labour time. She ${ }^{7}$ needs to eat, drink, sleep, rest, make love, and get involved in other activities in order to renew her labour power on the daily basis on the one hand, and reproduce herself in the bodies of her children on the other. The social barrier consists in the limitation of the labour day by the laws that result from the struggle of working class, on the one hand, and the concerns of more farsighted representatives of capitalism for the reproduction of a healthy and effective labour power, on the other. Faced with these limitations capitalists can increase and indeed do increase surplus labour time by cutting the necessary labour time. We can illustrate this by the following graph.

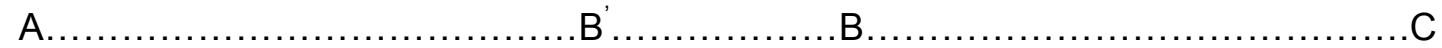

Now, while $A C$ has not changed, necessary labour time is $A B^{\prime}$, and the surplus labour time is $B^{`} C$. The new necessary labour time is smaller by $B^{`} B$ from the old one, and therefore, the new surplus labour time is larger than the old one by $B^{\prime} B$. The surplus value, which is produced in this way, is called by Marx relative surplus value (Marx 1976, chapter 12).

Information in the form of applied science and technological, innovations which enhance labour productivity, is a decisive factor in the production of relative surplus value. ${ }^{8}$ As mentioned, necessary labour time reproduces the value of labour power and this value in its turn is equal to the sum of the values of commodities that are consumed by the worker and her family. Therefore, the shortening of necessary labour time requires the reduction of the value of these commodities. Theoretically, we can imagine two ways for the reduction of the value of these commodities. The first is to cut the quantity of use values that are consumed by the worker and her family, and the second is to increase labour productivity in those branches of production that produce the consumed items. The first is damaging to labour power on the one hand, and may also provoke social unrest on the other. Therefore, capital avoids it if it can afford to do so, though it is implemented in certain conditions, for example in times of crises. Therefore, the second is actually the main method of producing relative surplus value. Labour productivity is increased by two interrelated factors: changes in the organisation of labour (division of labour and cooperation) on the one hand and enhancing the efficiency of the instruments of labour through the invention of new machines or the modification of existing ones, on the other. The application of science, i.e. information to production plays a central role in this respect. In this way while lacking a value itself information is the main lever of the production of relative surplus value. Marx (1976) argued that the main cause of successive technological revolutions is the production of relative surplus value. However, an im-

\footnotetext{
${ }^{7}$ I consistently use the pronoun "he" for the exploiter and "she" for the exploited in this article, unless the pronouns refer to concrete individuals.

${ }^{8}$ Workers' practical and tacit skills and knowledge are important factors of labour productivity and hence also factors of the production of relative surplus value. However, as mentioned in the introduction, they do not qualify as information in this context. Thus, the investigation of their impacts on the production of relative surplus value is beyond the scope of this essay.
} 
portant note is in order here. The growth in the labour productivity that reduces the value of labour power is an unintended consequence of the competition between individual capitals. Each individual capitalist constantly tries to improve the productivity of his enterprise in order to cheapen his commodities, and thereby pocket extra surplus value (surplus profit) (Marx $1976,1981) .{ }^{9}$ To the extent that the capitalists who produce the commodities that are consumed by the working class cheapen these commodities they also cheapen the value of labour power, thus helping the capitalist class as a whole. Apart from facilitating/mediating the production of relative surplus value technological innovations also result in the increase of the rate of profit to the extent that they cheapen elements of constant capital (Marx 1981). ${ }^{10}$

\section{The Impacts of Information on the Distribution of the Total Global Surplus Value}

The surplus value, which is produced by individual capitalists, is gathered in one pool of total social surplus value and then is divided among different strata of exploiting classes in the realm of distribution in the forms of profit, interest, and rent. Industrial and commercial capitalists receive their share of surplus value in the form of profit, the money-lenders in the form of interest, and landowners in the form of ground rent (Marx, 1981). Holders of intellectual property receive their share of surplus value in the form of information rent (Teixeira and Rotta 2012; Perelman 2002, 2003; Zeller 2008; Harvey 2012; Rigi and Prey [forthcoming]). The revenues of media consist of both profit and advertising rent (Rigi and Prey [forthcoming]).

The distribution of the total social surplus value occurs through the intertwined mechanisms of competition and monopoly. As argued above, trade secret and intellectual property as the two major forms of information monopoly result in surplus profits and information rents for their respective owners. As both surplus profit and rent can be explained on the basis of the formation of the average profit and the general rate of profit first I summarise Marx's theory on these matters.

\subsection{The Average Profit, the General Rate of Profit and the Price of Production}

The value of a commodity (w) consists of three components: constant capital (c), variable capital $(v)$ and surplus value $(s)(w=c+v+s)$. Under the condition of free and perfect competition commodities are not sold for their values but for their prices of production. While the value of a commodity is created in the realm of production, its price of production is formed due to the interplay between supply and demand in the market.As surplus value is generated by variable capital, the magnititude of surplus value produced by a given individual capital, ${ }^{11}$ within a given rate of exploitation, ${ }^{12}$ has an inverse relation to its organic composition, ${ }^{13}$ i.e. the lower the organic composition the larger the share of variable capital , and hence, the higher the magnititude of the produced surplus value. From the viewpoint of the capitalist, however, it is not the variable capital (labour) alone that produces surplus value but the whole of capital, undivided into constant and variable capitals. In this way surplus value is transformed into profit and the rate of profit is determined by surplus value divided by the total capital. From this follows that within a given rate of exploitation the rates of profit of the same amount of different individual capitals with varying organic combinations must have

\footnotetext{
${ }^{9}$ We will return to this point below when discussing the impact of trade secrets on the distribution of surplus value.

${ }^{10}$ The growth of technology has also negative consequences for the capitalist mode of production. First, to the extent that it replaces labour by machines it results in the growth of the organic composition of capital (constant capital divided by variable capital) resulting in a tendency of the fall of the rate of profit and consequently a tendency towards systemic crisis (Marx 1981). Second, value becomes less and less the measure of social wealth in term of use value. This, from the point of view of humanity at large makes the capitalist mode of production redundant (Marx 1973).

${ }^{11}$ Individual capital refers to a capital invested by a certain juridical owner- it is contrasted to the total social capital invested by all capitalists (Marx 1981).

${ }^{12}$ Rate of exploitation is surplus value divided by variable capital.

13 The organic composition of capital is constant capital divided by variable capital.
} 
inverse relations to their organic compositions. However, under the condition of free competition the rate of profit is equalized for all capitals, regardless of their organic compositions. In other words a general rate of profit which is equal to the sum of total social surplus value divided by the sum of the total social capital is formed, i.e. capitals of a certain quantity receive an equal profit regardless of their particular organic composititions. This occurs through competition. As a result of the movement of capital between branches of different organic compositions the supplies of the commodities of branches with high organic compositions decrease and those of branches with low organic compositions increase. Consequently, the first branches can sell their commodities for prices above their values and second ones are forced to sell their commodities for prices below their values. In this way surplus value is transferred from the second branches to the first ones. This process continues until it reaches a balancing point in which a general rate of profit is shaped in which the same amount of capital receives the same amount of average profit, regardless of its organic composition. At this balancing point each commodity commands a price which Marx calls the price of production, and which is equal to capital + plus the average profit. The prices of production of commodities with organic compositions of capital above the average social organic composition (the total constant social capital divided by total social variable capital) are above their values. The prices of production of commoditiess with organic compositions equal to the average social organic composition are equal to their values. And, the prices of production of those with organic compositions below the social average are below their values. While the price of production of a given commodity can be above, below, or equal to, its value the total sum of prices of production of all commodities is equal to the total sum of their values (Marx 1981, 241-301). ${ }^{14}$

\subsection{The Impacts of Monopoly on the Distribution of the Total Surplus Value}

But what happens under monopoly conditions? There are three general types of monopoly: namely, economic, natural, ${ }^{15}$ and the legal monopolies (Hilferding 1981, 199-203). Economic monopoly is a result of the concentration and centralisation of capital and the consequent formation of trusts, cartels, and oligopolies who control financial and technological flows, major sources of raw material, means of transport, and markets, and fix prices (see Hilferding 1981, part III, 183-227). ${ }^{16}$ Here, the power of monopoly is a reflection of the economic power of the monopolist. Natural monopolies are results of landed property. "Landed property presupposes that certain persons enjoy the monopoly of disposing of particular portions of the globe as exclusive spheres of their private will to the exclusion of all others" (Marx 1981, 752). Thus, the power of natural monopoly stems from the ownership of land. ${ }^{17}$ While trade secrets act as an interface between economic and legal monopoly, intellectual property is the quintessential form of legal monopolies. The legal monopoly differs from natural monopoly in that the monopolised object is not naturally scarce, but is artificially made scarce. Therefore, the power of legal monopolies stems only from legal entitlement. Although both natural and legal monopolies have much longer histories than capitalism, capitalism dramatically expanded, modified, and integrated them into the requirements of the accumulation of capital. With the transformation of capitalism based on free competition into monopoly capitalism, natural and legal monopolies have become essential instruments of the economic monopoly.

\footnotetext{
${ }^{14}$ The statement that the total sum of prices of production of commodities is equal to the total sum of their values known as the transformation problem, has been a thorny controversy since Böhm-Bawerk's (1984/1884) critique of Marx (see Harvey 1999/82, 61-68; Mandel 1981, 9, 13-29). Here, I accept Marx's thesis on the matter, without any further elaboration on the controversy.

15 The adjective of "natural" is used in this context as a contrasting device. Landed property and its resources, which represent the natural monopoly, have historical origins, express social relations, and are defined and enforced by the law and the state.

${ }^{16} \mathrm{~A}$ discussion of the formation of monopoly capitalism is beyond the scope of this article. The reader is referred to classic works by Hilferding (1981/1910), Lenin (1963/1916), Mandel (1975/1972), and Baran and Sweezy (1966).

17 Scarcity of particular types of land such as land usable in agriculture or land containing certain minerals, forests, waterfalls or other natural elements that can be used as means of production is a foundation of natural monopoly.
} 
The latter is more durable and more effective when supported by the formers (Hilferding 1981/1910, 202-203).

These three types of monopoly influence differently the distribution of surplus value among the different strata of exploiting classes. Economic monopoly is the means of generating surplus profits (profit above the average profit) for monopolistic capital (Hilferding 1981/1910; Mandel 1975/1972). Natural and legal monopolies entitle owners not only to a portion of surplus value regardless of his/her role in production but also to a portion of the revenues of wage earners and self-employed workers.

The revenues that are generated by natural and legal monopolies result purely and simply from ownership and therefore as Marx (1981, 908-909) noted are tributes. As it will be discussed below the extraction of such a tribute becomes explicitly coercive in the case of intellectual property. In classical economic theory, including Marxism, this tribute is called rent (Marx 1981). Ground rent, rent from advertisement space ${ }^{18}$ and information rent are the three major general forms of rent. In this paper we are concerned with information rent.

\subsection{Information Monopolies and the Distribution of the Total Surplus Value}

Information monopolies have two forms: trade secrets and intellectual property. Trade secrets and intellectual property differ in that in the former information is kept secret while in the latter it is traded as a commodity. The trade secret helps its holder to increase his share of the total social surplus value by influencing the prices of commodities of which information is a component, or a production or a marketing condition. The owner of intellectual property, by contrast, extracts a portion of the total social surplus value by selling information. Below, I will first discuss the trade secret and the surplus profit and rent that it generates very briefly and then explore more thoroughly information rent.

\subsubsection{Trade Secret, and Surplus Profit and Rent}

David Almeling $(2012,1107)$ defines trade secret "as any information that is secret, derives economic value from secrecy, and is the subject of reasonable measures to maintain its secrecy [...]" (Alemling 2012, 1107). This definition accords with WTO's definition of trade secret (Lippold and Schults 2014, 5). The major types of trade secret are: technical information; confidential business information; and know-how. The first refers to "industrial processes, blueprints and similar information", the second includes "customers lists, financial information, business plans and similar in formation", and the third "is information about methods, steps, and processes for achieving different results" (Lippold and Schults 2014, 6).

Dave Drab (2003, 4), a specialist in economic espionage, lists the following sixteen instances of trade secrets:

1. Formulas

2. Research

3. Blueprints, Diagrams

4. Confidential Documents.

5. Software

6. Implementation Methodology

7. Technological Records

8. Biomedical Records

9. Access and Control Information

10. Project Information

11. Pricing Information/Sale forecasts

12. Financial Information

13. Software Code

14. Test Material, Prototypes, Design Specification

15. Customer Business Information

\footnotetext{
${ }^{18}$ Robert Prey and I have explored rent from advertising space elsewhere (forthcoming).
} 


\section{Engineering Plans and Drawings}

These instances can be classified into: 1) innovations that enhances labour productivity; 2) information about aspects of organisation that enhance labour productivity; 3 ) information about supplies, contracts and financial arrangement that reduce constant and variable capitals and thereby enhance rate of profit; 4) designs for the production of new commodities or the modification of existing ones; 5) information about sales and marketing strategies and potential and actual customers, trade pacts, etc.; and 6) Information about financial conditions and affairs of an enterprise that influences its stakeholders, its reputation, and the value of its shares in stock markets (Lippold and Schults 2014; Almeling 2012; Drab 2003; Passman, Subramanian and Propkop 2014).

A trade secret that enhances labour productivity enables the monopolizing enterprise to produce its commodities for a price of production below the average price of production. It, usually, sells them for a price above its own price of production but below the market price. This helps it to acquire a surplus profit per unit of commodity, on the one hand, and a larger share of the total market for that commodity, on the other (Marx 1976, 1981; Mandel 1975/1972; Caffentzis 2013). ${ }^{19}$

The monopoly over the design for a new product helps the monopolizing enterprise to monopolize the market for a new product, set a monopoly price for the product and thereby extract surplus monopoly profit (Mandel 1975/1972, chapter 8).

Trade secrets concerning sales and marketing strategies and potential and actual customers help their holders to acquire larger shares of markets and cut the circulation time and thereby increase profits. And trade secrets about financial aspects help an enterprise to hide its weaknesses and strengths from competitors, shareholders, lenders, governments and other stakeholders.

In short, while trade secrets of an enterprise as instances of information have no value, they are vital for sustaining its profitability. An important note is in order here. If the commodity that trade secret is a component/condition of its production or a condition of its sale is itself information, the revenue is rent instead of profit, because, the value of information tends to zero. I will discuss this more thoroughly below in the section on intellectual property. However, regardless of whether the revenue of an enterprise is mainly profit or rent it is a portion of the total surplus value that is produced by the total working class in the world. As trade secrets are overwhelmingly concentrated in the advanced capitalist economies, this means that these economies extract enormous surplus value from the workers of the rest of the world by trade secret monopolies.

Due to secrecy, there are no figures on "value"20 of trade secrets. However, estimates of trade secret theft, the growth of the so-called intangible assets of companies, which include trade secrets, and media attention to trade secrets indicate the significance of such a value (Alemling 2012). According to Passman et al $(2014,3)$, the value of trade secrets, stolen annually, is equal to 1 to 3 percent of the GDP of the USA and other advanced capitalist economies. Dave Drab $(2003,3)$ reported that during one year alone (July 2000-June 2001) 1000 companies lost between 55 and 59 billion dollars in trade secret theft. FBI director Robert S. Muller III claimed that due to economic espionage US companies lost approximately $\$ 200$ billion annually (ibid). Now, if we assume that Muller is correct and assume further that the lost trade secrets consist of $4 \%-10 \%{ }^{21}$ of the total US trade secrets, the value of US total trade secrets will be equal to $\$ 2-5$ trillion.

\footnotetext{
${ }^{19}$ The extraction of this form of surplus profit is based on the same method as the extraction of the differential rent II described below, therefore, it has also been called "technological rent" (Mandel 1975/1972). However, they are different in that: 1) surplus profit is pocketed by the investing capitalist while rent goes into the pocket of the landlord; 2) surplus profit is temporary and vanishes as soon as competitors catch up with the labour productivity. Rent, on the other hand can be perpetuated for a longer period through political and institutional arrangements, which enforce property rights (see Zeller 2008, 95).

${ }^{20}$ As argued a trade secret as an instance of information has no value, in the Marxian definition of value. Thus, the term value is not used here in its Marxian sense.

${ }^{21}$ Although my choice of $4 \%-10 \%$ is not based on empirical evidence it is approximately reasonable. According to Passman et al $(2014,3)$ trade secret theft is equal to $1 \%-3 \%$ of the US GDP. It is reasonable to assume that
} 
The two following tables on the growth of companies' intangible assets and media attention to trade secrets in the USA also testify to the significance of trade secrets.

\begin{tabular}{|c|c|c|c|c|c|}
\hline Year & 1975 & 1985 & 1995 & 2005 & 2009 \\
\hline $\begin{array}{l}\text { Percentage } \\
\text { of intangible } \\
\text { assets }\end{array}$ & $17 \%$ & $32 \%$ & $68 \%$ & $80 \%$ & $81 \%$ \\
\hline
\end{tabular}

Table 1: Percentage of the intangible assets of the 500 companies that make up Standard and Poor 500 during 1975-2009 (Almeling 2012, 1093).

\begin{tabular}{|c|c|c|c|c|}
\hline Decade & 1970s & 1980s & 1990s & 2000s \\
\hline $\begin{array}{c}\text { Numbers of } \\
\text { articles in } \\
\text { major } \\
\text { newspapers } \\
\text { on trade } \\
\text { secrets }\end{array}$ & 1 & 159 & 548 & 593 \\
\hline
\end{tabular}

Table 2: Media attention to trade secrets from 1970s to 2000s in the USA (Almeling 2012, 1093).

\subsubsection{Intellectual Property Monopoly and Rent}

Intellectual property, in this context, consists of trademark, copyright and patent (Blank et al 2012). I will define each form in the due place. As mentioned, the holders of intellectual property acquire their share of the total social surplus value by selling information. The price they charge is information rent. "All rent is based on monopoly power of private owners of certain assets" (Harvey 2012, 90). While Marx (1981) and Marxists (Fine 1979; Harvey 1999/1982) have furnished us with sophisticated, though still unfinished (Harvey 1982), theories on ground rent, critical theories of information rent are still in the emerging phase. We can distinguish between two major trends in critical theories. The first is represented by those who try to theorize information rent on the basis of Marx's theory of value and in analogy to ground rent (Perelman 2002, 2003; Teixeira, and Rotta 2012; Zeller 2008; Harvey 2012; Foley 2013; Rigi and Prey [forthcoming]). This group considers value and surplus value produced by the total global working class as the ultimate source of rent. The second trend represented by Antonio Negri and his associates, argues that the prevalence of rent in the contemporary capitalism signifies the demise of the law of value and industrial working class (Hardt and Negri 2009; Hardt 2010; Vercellone 2010; Negri 2010; Marazzi 2010). As a proponent of the first trend I do not extensively engage the second position here, as I have done this elsewhere (Rigi n.d.). However, some brief critical remarks are in order. Negri and company argue that in the so-called post-Fordist capitalism (Hardt and Negri 2000), or in Vercol-

such a theft constitutes a higher percentage of the total value of trade secrets for the reason that US GDP is larger than the total value of the trade secrets of its firms. Firms underreport trade secret theft. They Fear that this may damage their reputation or may leak information to their competitors (Alemling 2012). Yet, it is hard to assume that more than $10 \%$ of US trade secrets are stolen annually. 
lone's terms "cognitive capitalism" (Vercellone 2010), the law of value is in crisis, and the role of capital in relation to production has become external, i.e. workers organize cooperation independently from capital. Therefore, they argue, capital appropriates value from a position, which is external to production, and this externality of capital to the production process has transformed profit into rent (Hardt and Negri 2009; Vercellone 2010; Negri 2010; Hardt 2010).

From a Marxist point of view this approach has four major problems. First, the law of value has never so pervasively governed the world economy as it does today (Rigi n.d.). Second, the externality of capital to production is a dubious claim (see for example Castells, 2010/1996; Rigi n.d.). Third, in Marxist theory, rent is a portion of the total abstract social labour, which is crystallized as value and a major part of rent originates from surplus value (Marx 1981; Harvey 1999/1982). Negri and his associates (Hardt and Negri 2009; Hardt 2010; Vercellone 2010) claim that the origin of rent is the expropriation of "the common"22 by capitalists, depicting such an expropriation as a process of primitive accumulation. Certainly, the enclosure of commons is a precondition for the extraction of rent. But such an enclosure in itself does not explain the origin of rent either for landed property or for intellectual property. Commons of information like unworked land do not embody value; therefore, they cannot be the origin of rent, which is value. They are only preconditions for rent. The value (rent) that information is exchanged for must have already been created elsewhere. While Negri and company reject that the surplus value produced by abstract social labour is the origin of this value, they fail to identify any other source for it. This paper argues that rent is overwhelmingly a portion of the (surplus) value that is produced by the wage labour that is exploited in the capitalist mode of production (Marx 1981), though the value extracted from unwaged labour also significantly contributes to it. The initial enclosure of land or information as an act of plunder and dispossession is definitely a presupposition for the extraction of rent. However, the extraction of capitalist rent proper is not identical with plunder. It is a mechanism of the exploitation of surplus value producing working class.

Finally Negri and company conflate rent, on the one hand, with profit and with interest, on the other. As George Caffentzis (2013), critiquing Vercellone's notion of "cognitive capitalism" (Vercellone 2010) argues, capitalism has witnessed a progressive separation of ownership of capital from the management of production since the late $19^{\text {th }}$ century (see also Marx, 1981; Hilferding, 1981/1909; Baran and Sweezy 1966). Major sections of the capitalist class play no role in production. Yet, they earn profit or interest but not rent. Profit is a yield on capital invested in the production or realisation of surplus value, regardless of whether the capitalist directly manages the investment or his representatives do this for him. Marx devoted a considerable part of the first volume of Capital $(1976,283-426)$ to the analysis of the production of absolute surplus value through the so-called "putting-out" system. In this system the capitalist did not play a role at all or played a very minor one in organising the labour process. To my knowledge, Marx never described the profits that were generated through this system as rent. Marx dealt more extensively with the issue of rent in Capital III and Theories of Surplus Value II. Nowhere in these two books Marx equates rent with this type of absolute surplus value. Profit is the fruit of the investment of value (capital) in production or circulation of commodities. Rent is, on the other hand, as it will be discussed below, the exchange of a use value of an asset that has no value, for value. As it was mentioned above in the section on trade secret (and will be discussed further below), when capital is invested in the production of information the revenue is rent instead of profit. But, this has nothing to do with whether the investor directly manages the production process or someone else does this for him. It stems from the fact that information value tends to zero.

Likewise the interest on loaned capital is also earned from a position of externality to the production, but it too is not rent. Although interest is received in exchange for the use value of money-capital, money-capital is value, while unworked land and information are not value.

\footnotetext{
${ }^{22}$ Hardt and Negri define the common as follows: "By 'the common' we mean, first of all, the common wealth of material world - the air, the water, the fruits of soil and all nature's bounty [...] We consider the common also and more significantly those results of social production that are necessary for social interaction and further production, such as knowledges, languages, codes, information, affects, and so forth" (2009, viii).
} 
In the capitalist context the main use value of money-capital is the production of surplus value. Thus, interest is the exchange of use value of value (money-capital) for value while rent is a value that is received in exchange for a use value that has no value (see also Teixeira and Rotta 2012, 8-12). Even, when the money is borrowed for the purpose of purchasing household items and not for that of investing the lender considers it as money-capital and, therefore, interest remains as a yield on money-capital. Negri and associates systematically conflate rent and interest by depicting rent as a yield on the financial capital. This is particularity evident in Marazzi's (2010) and Vercellone's (2010) discussions of finance capital. Marx (1981, 755-764) emphasised the distinction between rent and interest in order to critique the kind of conflation of the two that is made by Marazzi and Vercellone.

Now let us turn to the Marxist theory of rent. Below, first, I give a brief account of Marx's (1981) theory of ground rent and, then, on the basis of that, construct a theory of information rent.

\subsubsection{Marx's Theory of Ground Rent}

David Harvey defines ground rent as follows: "Rent, in final analysis, is simply a payment made to landlords for the right to use land and its appurtenances (the resources embedded within it, the building placed upon it, and so on)" (1999/1982, 330). Marx (1981) distinguished four types of rent in relation to landed property: absolute rent, differential rent I, differential rent II, and monopoly rent (see also Harvey1999/1982, 349-358.).

The general rate of profit of the total social capital does not apply to commodities that are produced in agriculture and extractive industries. There are two reasons for this. First, the organic composition of capital in these sectors is lower than the average organic composition of the total social capital. Thus, in agriculture and extractive industries the same amount of capital produces more surplus value that it produces in manufacturing. Second, landed property, functioning as a barrier to the free entry of capital, prevents the outflow of this additional surplus value for the sake of the formation of the general rate of profit. The additional surplus value remains within the landed property and is accrued to landowners in the form of rent.

Due to the relative scarcity of land combined with monopoly ownership of land the market price of a commodity produced on landed property is determined by the market price of the instance of that commodity which is produced on the land that has the lowest labour productivity (fertility). In other words the commodity is sold above its price of production. The capitalist who uses the worst land must pay the difference as a rent to the landlord in exchange for the permission to use it. Marx called this type of rent "absolute rent" (Marx 1981, 895-899; Harvey 1999/1982, 350-353). ${ }^{23}$ The capitalist in his turn must be able to make an average profit; otherwise, he will invest elsewhere. Thus, the market price of the commodity produced on the worst land is equal to the production price + absolute rent.

A capital that is invested in land with higher labour productivity produces its commodities cheaper but sells them at the market price that is fixed by the worst land, and therefore, it makes a surplus profit. This surplus profit is transformed into differential rent to the extent that the capitalist is forced (by contract) to pass it on to the landlord (Marx 1981). If the higher labour productivity is a result of the natural properties of the soil the resultant rent is differential rent I (Marx 1981); But, if the productivity, on the other hand, results from additional capital investment, it generates the differential rent II (Marx 1981).

Monopoly rent originates from a monopoly price, which in its turn results from the fact that a commodity is construed as exclusive (Marx 1981; Harvey 1999/1982, 2012). Such a price depends on the relative exclusivity of the commodity, on the one hand, and the demand for it, on the other. Harvey, explain this as follows: "Monopoly rent arises because social actors can realize an enhanced income stream over an extended time by virtue of their exclusive

\footnotetext{
${ }^{23}$ Ernest Mandel (1981, 65-67, 1975/1972, 378-384) argued that in the advanced capitalist countries such as the USA, Germany and Japan absolute ground rent had diminished for two reasons. First, the distinction between landowner and capitalist was vanishing, as capitalists increasingly owned the land they used. Second, the industrialisation of agriculture had resulted in the rise of organic composition of capital in that sector, diminishing agricultural surplus profits $(1975 / 1972,382)$.
} 
control over some directly or indirectly tradable item which is in some crucial aspects unique and non-replicable" $(2012,19)$. Marx $(1981,908)$ mentions exclusive wine produced on a special vineyard as an example of such an item. The price of land itself, to the extent that it originates from the uniqueness of the commodity that is produced on it, is capitalised monopoly rent. The same is true of the price of a painting by Van Gogh or Picasso.

We need to emphasize the difference between monopoly rent and absolute rent. Marx $(1981,911)$ argues that while both absolute rent and monopoly rent are accompanied by monopoly prices, in the first monopoly price is generated by rent, and in the second rent is generated by monopoly price. In the case of absolute rent monopoly price is equal to the price of production of the commodity plus absolute rent: absolute rent is the cause of monopoly price. As absolute rent is paid in exchange for the use of land, the related monopoly price arises from the landed property itself. Here, the excess of monopoly price over price of production is determined by the size of absolute rent. Monopoly rent, on the other hand, arises from the uniqueness of the commodity that enables the seller to sell it above its price of production. The difference between the price of production and the monopoly price is monopoly rent. Here, the size of rent is determined by this difference. Furthermore, the surplus value that is transformed into absolute rent is produced on landed property, the surplus value that is transformed into monopoly rent, on the other hand, is not necessarily produced in a particular branch of production. It is a share of the total social surplus value, even when landlord extracts monopoly rent.

Absolute rent is a comparative category that is established on the basis of productivity: it is paid to the owner of the least productive piece of land among a range of pieces of land that are used in the production of a certain commodity. Absolute rent is defined in opposition to differential rent. ${ }^{24}$ Monopoly rent on the other hand has nothing to do with comparative productivity per se but rather with the exclusiveness of the commodity itself.

\subsubsection{Information Rent}

Paraphrasing Harvey (1999/1982, 330), we can define information rent as "a payment made to" the owner of intellectual property "for the right to use" information. Now, information in contrast to unworked land, which is a gift of nature, is a human product. Further, the production of certain kinds of information requires the investment of capital. Then, why is this payment considered rent instead of being interest or profit? Critiquing Negri and associates' conflation of rent and interest above, I argued that interest is the price of money-capital, which is a form of value. Any commodity that has a value can be lent like money for a certain period of time in exchange for interest. For example, if a machine is lent for a year, by the end of the year the user must pay a sum of money to the owner that is equal to the value of wear and tear of the machine during use plus an interest on the price of the machine before it was used. Information price is paid for a use value that has no value therefore it cannot be interest (see also Teixeira and Rotta 2012, 8-12).

The price of information cannot be profit either. This claim seems to be contradicted by the fact that the productions of some instances of information require investments of capital. As argued earlier, Marx (1981) teaches us that any invested capital regardless of whether it produces value or not is entitled to a certain amount of profit from the total social surplus value calculated in proportion to its size according to the general rate of profit. There are two major instances of capitals that do not produce value but still receive profit: capital invested in fully automated production and commercial capital. A fully automated production process lacking variable capital does not produce new value but only transfers the value of the constant capital to the commodity (Caffentzis 2013). Neither do commercial operations (purchases and sales) produce new value (Marx 1981, 1993). However, both of these types of capital receive profit. Then, why is the revenue from capital invested in the production of information rent instead of profit? The answer to this question is as follows. The act of sale transfers the commodity that is produced by the automated enterprise from the owner to the

\footnotetext{
${ }^{24}$ If there is no differential rent i.e. all pieces of land, which are used in the production of a certain commodity have the same productivity, an unlikely scenario, then, all rent will be absolute rent.
} 
buyer. The same is true of commercial capital. The producer of a commodity or a merchant loses the ownership of a commodity he sells. He cannot sell the same commodity twice. This means that he cannot repeatedly make profit from the same investment. In order to renew his profit he must invest new capital into production or purchase of new commodities. In the case of ground rent the same piece of land can be repeatedly, though sequentially, rented. Of course, land that is sold is also transferred from the seller to the buyer. But, in this case, the price of land is capitalised rent (Marx 1981, 911). The owner of intellectual property who receives a fee from the user does not transfer the ownership of intellectual property to the user. He does not sell the intellectual property but leases it as the landowner leases land. However, in contrast to land that can be only leased to one juridical person for a certain period of time, information can simultaneously be leased to an infinite number of people. Thus, the capitalist who invests in information earns rent not profit. The minimum amount of this rent must be equal to the average profit; otherwise, the capitalist will invest elsewhere. However, to the extent that information is not substitutable the rentier, setting a monopoly price, earns a rent, which is above the average profit. If the owner of intellectual property sells his right over it to another person, in this case the price of the intellectual property is capitalised rent.

If the price of information is rent, then, how can Marx's concepts of the ground rent be applied to information rent? This paper proposes the following hypothesis. 1) All three forms of intellectual property namely trademarks, copyrights and patents generate monopoly rent; Monopoly rent is the most common form of information rent. 2) Copyrights and patents can also generate differential rent. 3) Absolute information rent is unlikely to exist. This hypothesis advances further the concept of information rent compared to Harvey (2012), Zeller (2008), Teixeira and Rotta (2012), and Foley (2013). First of all, none of these authors, except Foley, use the term "information rent". Harvey (2012) only considers monopoly rent, which arises from branding. Thus, he does not develop a concept of differential information rent. Zeller, and Teixeira and Rotta use the term knowledge rent and try to analyse it in general. Zeller (2008, 97-99), however, erroneously claims that patent rent is absolute rent and patent differential rent does not exist (see below). Teixeira and Rotta $(2012,14,14-16)$ recognize the possibility of differential "knowledge rent" rent. But, they seem to suggest that any information that is applied to production enhances labour productivity and, therefore, results in differential information rent. This seems to me to be a mistaken assumption. As I will show below only certain information enhances labour productivity and such information only in certain circumstances results in differential rent. Foley recognizes information rent without specifying its forms.

Below I elaborate on this hypothesis by considering forms of rent that arise from different forms of intellectual property. I emphasise that information rent in all its forms is different from ground rent in that the former is a portion of the total social surplus value while the latter is part of the surplus value that is produced on landed property.

\subsubsection{Monopoly Rent from Trademark}

"Trademark is a sign that distinguishes the goods of a given enterprise from the goods of its competitors" (WIPO Handbook 2008/2004, 68). This paper argues that top trademarks called brands (Arvidsson 2006) generate monopoly information rent. Let's reiterate that monopoly rent arises out of the ownership of a tradable asset that is considered to be unique (Marx 1981; Harvey 1999/1981, 2012). Applying the criterion of uniqueness to information we encounter the following problem: as discussed earlier an item of information is infinitely replicable at negligible extra cost and therefore its value tends to zero. In this sense it is not unique, because, the use value of each copy is the same as that of the original. However, while a piece of information is infinitely replicable in relation to itself, it remains unique compared to all other pieces of information. In other words, while a piece of information in terms of quantity is infinitely replicable, in terms of quality it is unique. For instance compare the two following theorems $(a+b)^{2}=a^{2+} b^{2}+2 a b ;$ and, $(a+b)^{3}=a^{3}+b^{3}+3 a^{2} b+3 a b^{2}$. While each can be infinitely replicated they remain unique in comparison to each other. The same is true of the 
brand names like Apple or Samsung. While each can be infinitely attached to different products, when compared with the other, they are unique. The holder of intellectual property considers this uniqueness as his own property and indeed exchanges it for monopoly rent, albeit with as many buyers (renters) as possible. As we argued earlier, quoting Marx, all rent is a tribute, because, both landed property and intellectual property, like any property, are protected by the law which is backed by the violence of the state. However, in contrast to the natural scarcity of land, intellectual property is artificially made scarce by the force of the lawstate. Hence, the arbitrariness of intellectual property is far more obvious and less naturalised than that of landed property. Thus, information rent more explicitly takes the form of tribute than ground rent does so, therefore, we can call it information rent-tribute.

As said, all three types of intellectual property, namely trademark, copyright and patent generate monopoly rent-tributes. Trademark, in this respect stands out by only generating monopoly rent. It cannot generate differential rent because it only influences prices in the realm of the market. It has no direct impact on the processes of production, which in certain circumstances result in differential rents. Trademarks, ${ }^{25}$ particularly brands, are meant to stimulate demand. To the extent that the surplus demand resulting from the trademark/brand results in a market price above the price of production, it generates monopoly surplus profit. Now, if the trademark/brand is franchised to another party the franchisee must pay the whole or the part of this monopoly profit to the franchiser as a monopoly rent. As Harvey (2012) argues the surplus profit generated by a trademark or brand is threatened by competition from other trademarks and brands that denote commodities with comparable qualities. In the case of tight competition the margins of surplus profit decrease by being distributed among several brands. However, as Arvidsson (2006) argues, the top, most well established brands can also charge premium prices. Ordinary trademarks, on the other hand, must be satisfied with selling their goods at the average market price. To illustrate this, we can look at the price differences of a small Americano cup of coffee in my neighborhood in Budapest:

\begin{tabular}{|c|c|c|c|c|}
\hline & $\begin{array}{c}\text { Ordinary coffee } \\
\text { shops }\end{array}$ & California & Costa & Starbucks \\
\hline Price & 320 & 450 & 690 & 690 \\
\hline
\end{tabular}

Table 3: Price differences of a small Americano in Budapest (prices are in the Hungarian Forint [1 Euro is equal to 300 Forint]).

If we assume that the price of 320 yields an average profit then California, Costa, and Starbucks each respectively earns a surplus profit of 130,370 , and 370 FTs over a small cup of Americano. Indeed, all these three brands in my neighborhood are franchises and each franchisee pays monopoly rents to the respective franchiser. The same can be true of a pair sport shoes (or any commodity) of the same quality. Brands like Nike and Adidas, etc., can make surplus profits compared with less sought-after brands, depending on the elasticity of demand. While the competition between brands pushes down the margins of surplus profit for each, all top brands still earn considerable surplus profits. The formation of an oligopoly is a way to counteract competition and keep monopoly prices high (Harvey 2012). Thus, we can generally assume that brands result in monopoly surplus profits. Therefore, when franchised they also generate monopoly rents.

There are also very exclusive brands such as Rolex or Mercedes Benz that have few substitutions. Only a few other brands such as Omega or BMW can respectively function as substitutes for Rolex or for Mercedes. For instance in the watch market most ordinary trademarks

\footnotetext{
${ }^{25}$ I will explore the political economy of branding more extensively in a separate article where I will critique Hardt and Negri's (2000) concept of affective labour and Arvidsson's use of it (Arvidsson 2006, 2009; Arvidsson and Colleoni 2012) .
} 
such as Seko and Citizen, etc. are substitutable. Thus, one can buy a reasonably good watch for a price under $\$ 100$. On the other hand, as the following table illustrates there are watches that are priced at millions of USDs.

\begin{tabular}{|c|c|}
\hline Name of Brand & Price (in US\$) \\
\hline Louis Moinet Meteoris & $4,600,000$ \\
\hline Hublot-Big Bang & $5,000,000$ \\
\hline Pate-Philippe-Henry Graves & $11,000,000$ \\
\hline Chopard 201-Caral & $25,000,000$ \\
\hline $\begin{array}{c}\text { Bregut Grande Complication Maine- } \\
\text { Antoinette }\end{array}$ & $30,000,000$ \\
\hline
\end{tabular}

Table 4: Price of watches by brand in US\$ (Source: http://www.exluxe.com/most-expensivewatches-world-2014).

Similarly, while most types of wine are substitutable, there are wines that can be sold for thousands of US\$ per bottle.

Any branded commodity has a price of production that in the absence of the brand would be the basis of the formation of its market price. The difference between this market price without the brand and the monopoly price that the brand generates is the price of the brand. This price is paid for a name that evokes certain images and associations. A name does not embody any value. Thus, the value that it is exchanged for it is produced elsewhere by value-producing workers. Adam Arvidsson (2006) argues that the premium value of a brand is mainly the result of the affective-symbolic aura of the brand created by advertisements, quality, history, etc. However, as Robert Prey and I (Rigi and Prey [forthcoming]) argue this "affective-symbolic aura" does not create value but instead transfers to the brand value, which is produced elsewhere. The arbitrariness of the price of brands is best illustrated by the example of modern art. Don Thompson (2008) demonstrates that the price of a piece of art jumps dramatically if it is exhibited in branded museums or galleries, bought by branded art collectors, sold by branded art dealers, or auctioned in branded auction houses. Thompson shows that these branded actors, who brand modern art, constitute a tight network. Put simply, branding determines the price of modern art. He mentions many examples of art that was initially purchased for a few thousands of dollars but sold for hundreds of thousand dollars after being branded. To sum up surplus profit that arises from brand is monopoly rent.

\subsubsection{Monopoly and Differential Rents From Copyright}

Copyright is the exclusive legal right of the creator of an original work to use and distribute it. The originality and the right apply to the form of work and not its content (WIPO Handbook $2008 / 2004,40-42$ ). The holder of copyright usually receives royalties from users. Purchased copyrighted information is either used by private persons or as a means of production by capitalists. In the first case the price is a monopoly rent and in the second it can be either monopoly or differential rent. 
In the first case, as the value of the sold information is zero the price is a monopoly rent extracted from the buyer. If the buyer is a wage earner or an independent worker the rent originates from her wages. But if the buyer is an exploiter, meaning that he lives through earning profit, interest or rent, the rent that he pays to the seller originates from the total surplus value that is produced by the totality of the working class. In both cases the extraction of rent is a mechanism for the exploitation of the working class. Prices charged for music, text, images, photos, films, etc., that are purchased for private consumption all represent this kind of rent. In the mechanical production of information, information is embedded in a material form such as paper, film rolls, cassettes, records, etc. The reproduction of the material form, other conditions being equal, costs the same as its production. Therefore, it includes value. Hence, the price of copyrighted information produced mechanically or by hand consists of the price of its material body plus the information rent. Information rent cannot exist independently from this material body and its price-the actual price of the commodity consists of these two parts. The price of digitally produced information, on the other hand, only consists of information monopoly rent, because it is not attached to a particular material body. Thus, in the digital era the rent earned from copyright acquires an independent existence of its own. And this constitutes a major difference between rent from trademark and rent from copyright. The commodity that a trademark marks exists independently from the latter, and can have a price of its own. But trademark cannot exist independently from the commodity it denotes. The surplus profit/rent accrued through trademark is earned on top of the market price of the commodity that it denotes. In the case of copyrighted digitally-reproduced information the rent and the price are one and the same. When branding plays a central role in the marketing of copyrighted information (for example, the name Microsoft attached to software; the name Harrison Ford to a film; the name of Lady Gaga to a song; etc.) the accrued information rent consists of rent from brand plus rent from copyright. For example, the extra sale of a film due to the name of a famous actor is brand rent.

In spite of the difference between them, rent from trademark and rent from copyright are both prices of copies of information that arise out of monopoly ownership and therefore, instances of monopoly rent.

Now let's explore the forms of rent which arise when copyrighted information is used as a means of production by a capitalist. Software, data, text, sound, images, film, photo, etc., are all used as such means of production. We can have one of the following cases. ${ }^{26}$

1. The same information is used as a means of production for the same commodity by different firms that have the same labour productivity. In this case all producers make the same profit per unit of capital and no one has a surplus profit. In this case, all users pay the same monopoly rent to the seller.

2. Different firms, which use the same information for the production of the same commodity, have different levels of productivity, but the information used has no impact on this difference. In this case, while some firms make surplus profits the seller of information cannot make any claim to their surplus profits. He must charge them the same price as he charges anyone else. Therefore, rent remains monopoly rent.

3. Information differently influences the level of productivity at different firms that produce the same commodity. (If it influences all productivities at the same rate it will not change their previous profits, because their relative productivities will remain the same). Firms whose relative productivity has been enhanced above the average productivity of the branch make surplus profits while other firms who use the same information make average profits. Theoretically, the owner of information may make claims to the surplus profits by trying to sell the information for higher prices to those who make surplus profits. This, however, requires, a dual pricing system: 1) firms

\footnotetext{
${ }^{26}$ Royalties as a form of rent do not constitute an element of constant capital as they are a portion of surplus value. Although a cost for the investor, rent does not enter value of constant capital. Value of constant capital is transferred to commodity. Rent is not an already existing created value that is transferred to commodity but is a component of that portion of value of commodity that is created by labour in the production process.
} 
which make average profits pay a fixed price for the information; 2) firms which make surplus profits pay on the top of the fixed price surplus prices in proportion to their surplus profits. Here, the fixed price constitutes a monopoly rent and the additional surplus prices are differential rent. But, the existence of such a complicated pricing system, and, thus, that of differential rent, is an unlikely scenario. Firms that make surplus profits can justifiably refuse to pay the extra prices arguing that the seller must charge everyone the same price for the same commodity. Therefore, they may try to hide from the seller the positive impacts of information on their productivity. While different prices for the same commodity by the same seller are theoretically plausible, they are not sustainable in practice. This eliminates the possibility of differential rent and, therefore, rent remains monopoly rent.

4. Copyrighted information, for example software, is designed as a productivityenhancing device in the production of a certain commodity and is monopolised by one or more firms (this form of information is usually patented). Here, information can help the monopolist or the oligopoly to make a surplus profit if it increases the productivity of the firm(s) that use(s) it above the average productivity of all firms that produce that commodity. In such a case, the seller of information can make a claim to the whole or part of surplus profits in exchange for not selling the information to their competitors. In this case rent is differential rent because it originates from a surplus profit that arises from labour productivity.

5. Absolute information rent whether from copyright or from patent is implausible. I will demonstrate this below where I critique Zeller's understanding of absolute rent.

\subsection{Monopoly and Differential Rents From Patent}

A patent is a legal document that is issued by a governmental agency. It describes an invention, defined as a solution to a technical problem and prohibits the manufacturing, using, selling or importing of the invention without the permission of the inventor for a certain period (usually 20 years) (WIPO Handbook 2008/2004, 17). An invention can be a thing or a process. Patents usually cover three areas: 1) a design-formula for a new product; 2) a marketing method; and 3) a productivity enhancing technology (Gallini 2002). Thus, as Alemlig (2012) argues, the spheres of patents and trade secrets overlap. However, patented information, unlike trade secret, is disclosed.

In the first case a patent results in a monopoly production of a product, which in its turn results in a monopoly profit. Thus, patent royalties are monopoly rent. Zeller (2008, 97-99), in an otherwise strong article, makes the claim that rent generated by patents is absolute rent. The reason, Zeller says, is that a patent is a barrier to the entry of additional capital into the production of a commodity that uses the patented information. But, monopoly being a barrier to capital is a necessary condition for all types of rent. "All rent is based on the monopoly power of private owners over certain assets" (Harvey 2012, 90). In all cases of rent, including monopoly and differential rent, this power functions as a barrier to capital. Marx is explicit on this in relation to differential rent: "Differential rent presupposes precisely the monopoly of landed property, landed property as a barrier to capital, for otherwise the surplus profit would not be transformed into ground-rent and would not accrue to the landlord instead of the farmer" $(1981,885)$. Absolute rent requires two additional conditions. First, the average organic composition of the whole branch in which the commodity is produced must be lower than the average organic composition of the total social capital. Second, the commodity must be produced with a capital that has the lowest labour productivity. In other words absolute rent is a portion of the surplus value that is produced in the branch itself but monopoly prevents its outflow for the sake of the formation of the general rate of profit. Zeller is attentive to this general argument but thinks that it is applicable to patents. He says that because the organic composition of capital in knowledge production is very low it follows that the rent that is accrued through patent is absolute rent $(2008,99)$. But the surplus value that is transformed into patent rent is not produced in the knowledge sector in the first place. As argued above knowledge has no value, and, therefore, the knowledge sector does not pro- 
duce surplus value at all. This surplus value is produced outside the knowledge sector. Furthermore, the surplus value that is transformed into surplus profit and ultimately into information rent is often not produced in the branch that uses the patent to produce another commodity either. As a rule, capital invested in information-intensive manufacturing and advanced-automated/semi-automated service sectors have higher organic composition of capital than the average organic composition of the total social capital. The reason is that these sectors are far more automated than other sectors. For example, consider a patented formula for the production of a special drug, the production of which is almost fully automated. While the organic composition of capital which is invested in the production of the formula might be below the social organic composition, that of the manufacturing firm is definitely above it. The pharmaceutical companies are usually highly automated and thus have high organic compositions of capital. This is true in general of semi-automated and automated manufacturing and service production that are information intensive industries. Therefore, the major shares of their profits consist of surplus value produced in more labour intensive industries elsewhere. It is true that some knowledge intensive industries such as health care and education are also labour intensive, and produce value and surplus value when privatized. However, a patent by no means can prevent the entry of additional capital into such branches. Although the monopoly over design/formula prevents others from investing in the production of the commodity, this by no means makes patent rent absolute rent, because, the origin of this rent is the total social surplus value. The reason is that the origin of the rent is the monopoly price.

Rents derived from patents will remain an example of monopoly rent even if the capital invested in the production of the commodity has an organic composition below the average organic composition of the total social capital. In this case patent rent is comparable with the monopoly rent that results from the ownership of a piece of land that is the source of an exclusive wine. Absolute information rent only arises if the two following conditions simultaneously exist: A) information is used in the production of a commodity in a branch of the economy with an organic composition below the organic composition of the total social capital; B) copyrights or patents function as barriers to additional investment of capital in the production of that commodity. This second condition is implausible unless the commodity cannot be produced at all without the use of information. If so, the commodity becomes a unique commodity and the rent is, therefore, monopoly rent even if the organic composition of the branch is below the organic composition of the total social capital. The producer of the commodity manipulating the supply side sells the commodity for a monopoly price and the rent also becomes a monopoly rent. Furthermore, information with lowest labour productivity in a certain branch of production is unlikely to be fenced by copyright or patent. It is rather universal commons.

Now let's consider the rent for patented information that concerns marketing methods. Such information usually, if not necessarily, helps the user to acquire a greater share of a certain market for a certain product and thereby earn surplus profits. Otherwise, the user will stop using them. The royalties that are paid for it are monopoly rents. The reason is that they are exchanged for the unique use value of the patented information.

When the monopoly over a patent enhances the productivity of a certain firm that produces a certain commodity, as mentioned in the case of copyright, it results in a surplus profit if it reduces the price of production of the firm below the average price of production of the branch that produces that commodity. This surplus profit is not a result of a monopoly price but a "differential" price and, therefore, the rent that is paid from it is differential rent. Copyright and patent relate similarly to productivity and differential rent. Therefore, what I have already said on copyright in relation to differential rent is also valid for patent. In both cases while the information is unique and a royalty is paid for this uniqueness the rent is not monopoly rent. The reason is that the uniqueness of the information results in producing another commodity, which is not unique but cheaper. Hence, royalties are paid in exchange for productivity. The productivity enhancing information, to the extent that it is not a trade secret, has increasingly been enclosed by patents (Gallini 2002), resulting in the growth of differential rent. 
To sum up, information mainly generates monopoly rents, though certain copyrights and patents also generate differential rents. Information rents whether monopoly or differential, unlike ground rent, do not originate from a particular branch of production but instead are a portion of the total social surplus value. This underlines a major difference from ground rent, which originates from surplus value that is produced within the landed property.

An important note is in order here. Ernest Mandel (1975/1972) argued that under monopoly capitalism we have two different general rates of profits. One for big monopoly capital which is above the general rate of profit of total social capital, and another for non-monopoly capital, which is below the general rate of profit of the total social capital. While a certain amount of monopoly capital earns a surplus profit above the average profit the same amount of non-monopoly capital earns a profit below the average profit. In other words monopoly transfers surplus value from the non-monopoly sector to the monopoly sector. Non-monopoly capitals, despite their low rate of profits, must pay rents to information owners for using information commodities; the big monopolies often produce and customise their own information. Small and medium companies rely on outside providers, particularly for software. Information rents that small and medium companies pay are a further squeeze on their profit. Such companies may try to squeeze worker wages in order to pay these rents.

\section{The Rise of the Information Economy, Neoliberalism and Globalisation}

I could not find data on the magnitudes of total profits and rents that are earned through trade secrets and intellectual property in the global economy. However, as the example of the USA (Alemling 2012; Blank et al. 2012) illustrates they are central to the advanced capitalist economies. $R$ and $D$, design, advanced manufacturing, such as pharmaceutical industry, and advanced services, which are based on trade secrets or are IP intensive, play a central role in advanced capitalist economies (Castells 2010/1996; Alemling 2012; Blank et al. 2012). Therefore, profits and rents that acquired through the monopolisation of information are also central to these economies (Perelman 2002, 2003; Zeller 2008).

The expansion of the role of information in the economy undermines the general rate of profit of the total social capital in two ways. First, the rentier capital that produces and sells information receives a considerable amount of the total social surplus value in the form of rent without itself contributing to this total surplus value. Second, the capital which is invested in automated and semi-automated information-intensive manufacturing and services, if it produces surplus value at all (the fully automated firms do not produce surplus value), contributes far less surplus value to the total social surplus value than the amount of surplus value that it receives back as profit from this total fund. Thus the total social capital grows faster than the total social surplus value. The result is a tendency towards the decline of the general rate of profit, which is also a tendency towards crisis (Marx 1981, 317-338).

This tendency is counteracted by the deployment of the following strategies: 1) the expansion of capitalism into labour intensive sectors; 2) intensifying the rate of exploitation by prolonging the labour day, intensifying the pace of work and cutting wages; 3 ) cutting social wages (the welfare state); 4) reducing the cost of constant capital particularly the raw materials that are imported from the periphery; and 5) extracting value from the non-capitalist sector through primitive accumulation (Marx 1981, 339-348; Caffentzis 2013, 127-138). These measures have been among the main characteristics of neo-liberalism since the 1970s (Harvey 2003). Thus, we can argue that the rise of the information economy has been a major reason behind the rise of neo-liberalism. It is important to note that the first four of these strategies operate within the normal regime of the accumulation of capital and only the fifth is related to primitive accumulation. We will return to this point below.

The deployment of the first strategy has resulted in the global expansion of labour intensive manufacturing, agriculture, and service industries. The global expansion of capitalist manufacturing and agriculture is such an obvious fact that it does not need further elaboration here. However, what needs to be emphasised is that a large part of the surplus value that is produced in the Global South is redistributed among advanced capitalist industries in the Global North. Thus, this surplus value is a major source of information surplus profit and 
information rent. Although service sectors are usually information-intensive, they are also labour intensive, except services that are almost automated. Therefore, most of them produce value and surplus value. Take for example a profit making university that earns its profit only from teaching (we ignore the rents it may earn from patents for the sake of argument here). Such a university sells education services not information, though the production of this service is based on the use of information. While this information can be reproduced at zero cost the reproduction of the service of teaching/education-other conditions be the same - has the same cost as its production. Education is obviously a labour intensive industry and the labour of teaching produces value and surplus value. The same is true of the privatized health care industry and, of many other service industries. Therefore, labour intensive service industries, with the exception of those that produce information commodities, produce more surplus value for the fund of total social surplus value than the surplus value they receive back from it in the form of profit. The difference is transferred to advanced information industries in the forms of information surplus profit and information rent. Thus, the globalisation of capitalist manufacturing and service sectors is also a major basis for the expansion of the information-based economy. This shows that contemporary capitalism is firmly governed by the law of value and is tuned to the production of surplus value by waged labour.

The second and third strategies mentioned above have been globally deployed in order to increase the rate of exploitation of waged labour, which is the rate of surplus value. While the second strategy increases the rate of surplus value directly the third does so indirectly by easing taxation on profit, rent and interest. The lowering of taxes on the revenues of exploiting classes increases their share of the total social surplus value. The fourth strategy, namely, the cheapening of the elements of constant capital, occurs partially through enhancement of the productivity of industries that produce them and partially through the employment of cheap labour. Either through the use of new technology or through the intensification of exploitation enhances labour productivity, or by both together. All these strategies are embedded in the production of surplus value and the increase in the rate of exploitation. Furthermore, the surplus value that is extracted from non-waged labour through the mechanism of primitive accumulation (Mandel 1975/1972; Harvey 2003; Caffentzis 2013) is another source of the total surplus value appropriated by the total global capital.

Thus, simply put, surplus value that is globally produced by waged and unwaged labour is the origin of information surplus profits and information rents. The imperialist dimension of these processes can hardly be exaggerated. The imperialist division of labour in which automation and advanced $R$ and $D$ are concentrated in the imperialist countries while less advanced manufacturing and services are located in the Third World works to transfer gigantic amounts of surplus value from the Global South to the Global North. This imperialist distribution of the total world's surplus value has been strengthened by the implementation of the neo-liberal financial regime. ${ }^{27}$ The IMF and the WB, which regulate the world financial system, have harnessed the economies of South for the interests of the North. In this system imperialists suck huge amount of surplus value from the rest of the world in the forms of surplus profits and rents (Perelman 202, 203). This is aptly illustrated by the position of the US in the global division of labour. Almost every industry in the United States produces or uses intellectual property. In 2010, 75 out of the total 313 American industries were IP-intensive, providing 27.1 million jobs that amounted to 18.8 percent of the total employment. The share of IP-intensive industries in relation to the total GDP was $\$ 5.06$ trillion or $34.8 \%$ of GDP in 2010. IP-intensive industry exported merchandise worth $\$ 775$ billion; $6.7 \%$ of the total merchandise exported in 2010. The export of IP-intensive service-providing industries amounted to $19 \%$ of total private service exports (Blank et al. 2012, vi-viii).

\footnotetext{
${ }^{27}$ Here is not the place to discuss different theories on the neo-liberal financialisation. The curious reader is referred to Arrighi (1994), Boyer and Saillard (2002), Teixeira and Rotta (2012), Marazzi (2010) and Harvey (2010). For classic Marxist theories of finance see Marx (1981) and Hilferding (1981).
} 
While the neoliberal financialisation of the world economy has been at the service of the information-based economies of the North, information surplus profits ${ }^{28}$ and information rents earned by trade secret and intellectual property have also provided further impetus for financialisation (Zeller 2008; Teixeira and Rotta 2012; Harvey 2010; Rigi and Prey [forthcoming]).

Primitive accumulation, largely resulting from financial operations, has been an important mechanism for the imperial extraction of information surplus profit and information rent. However, it is important to note that the main source of surplus value that is transformed into information surplus profit and information rent is not an example of primitive accumulation but rather of capital accumulation in its normal sense, i.e. the production of surplus value by waged labour. This is an important point because ever since David Harvey (2003) coined the term "accumulation by dispossession" the role of primitive accumulation has been exaggerated and used in unqualified ways. This is clearly evident in both Zeller's (2008) and Teixeira and Rotta's (2012) use of the term in their respective accounts of "knowledge rent". The first thing that needs to be noted is that accumulation by dispossession is not always the same as primitive accumulation. The source of primitive accumulation is always outside the capitalist mode of production. Cutting off welfare provisions, cutting wages and even the bankruptcy of capitalist enterprises are all examples of accumulation by dispossession. But these are not instances of primitive accumulation because they are inner mechanisms of capital accumulation. The dispossession of self-employed independent producers from their means of production and the extraction of value from them by unequal exchange are, on the other hand, mechanisms of primitive accumulation (Mandel 1975/1972). Although these mechanisms of primitive accumulation do still exist today their relative weight in the global economy compared with 1970 is much smaller. Then, major parts of the world economy were still outside the capitalist mode of production proper. Today, by contrast, the capitalist mode of production has conquered all corners of the world and thus the value that the capitalist mode of production itself produces is enormously larger than the value that it extracts from the noncapitalist outside. Therefore, today imperialism is more firmly grounded in the uneven geographies of the production of surplus value, though primitive accumulation remains an important imperialist mechanism. I concede that the expansion of capitalism since 1970 has been accompanied by a huge expropriation of independent producers and hence primitive accumulation. However, by now, this process is already almost completed. Thus in the current context, the mechanisms of primitive accumulation, though still important, play a secondary role compared with that of capital accumulation proper.

\section{The Intertwined Exploitation of Information and Non-Information Workers}

We have argued: 1) information has no value 2) the enclosure of information through trade secrets and intellectual property generates surplus profits and rents 3 ) such profits and rents are parts of the surplus value produced by workers who do not produce information. The conclusion is that the holder of information exploits the whole value producing working class. This, however, does not mean that capitalists do not exploit information workers who do not produce value and surplus value. These workers are also exploited, and their exploitation takes two forms. First, information capitalists extract surplus time from them even if this surplus time does not produce surplus value. The labour time of the majority of such workers is longer than the socially necessary labour-time for the reproduction of their labour power. While their work does not directly produce value and surplus value, it is an essential condition for the existence of capitalism. Without it the capitalist mode of production will collapse.

\footnotetext{
${ }^{28}$ Ground rent even to a greater extent has been a basis for financialisation. The interdependence of financial institutions and the construction industry so dramatically revealed in the crisis of 2008 provides ample evidence for this. Further, the oil rents that the Arab States earned in the wake of the hike of oil prices after 1973 supplied the money for the unprecedented expansion of banks in the US and UK. These banks became a major institutional pillar of neoliberalism and came to control the whole world economy, plundering particularly the Third World.
} 
As Christian Fuchs (2010, 2012 a, b) has argued information capitalists appropriate the whole labour time of unpaid information producers for free. ${ }^{29}$

In this sense both information workers and other workers have a common exploiter in capitalism. Two important notes are in order here. First, the privileged section of information workers may earn wages that are higher than the value of their labour power. Furthermore, the elite of such workers, a component of the labour aristocracy, may even earn wages that are higher than the value that their labour could potentially produce if deployed in spheres of value-producing production that produce value. To the extent that their wages exceed the value that their labour time can potentially produce, this elite exploits the surplus valueproducing working class. The excess of their wages over the potential value that their labour time may produce is a rent taken from a portion of surplus value produced elsewhere. This creates a certain contradiction between privileged information workers who overwhelmingly work and reside in advanced capitalist countries, and are male by gender, and workers in service sectors (overwhelmingly women), and manufacturing and agricultural workers who overwhelmingly work and reside in the Third World.

Second, the enclosure of the commons of information by means of trade secrets and intellectual property is an act of dispossession not only of those workers who are the direct producers of this commons, but also of humanity at large. As Marx $(1981,199)$ himself noted, commons of information are products of universal labour. Universal labour, which is performed through cooperation between generations of living and dead workers, itself uses the general intellect of humanity as its material. New innovations are the result of collective scientific work over decades or even centuries. Furthermore, education, research, and development, which are the foundations for the production of scientific information, are even in the United States, overwhelmingly funded by public money (Perelman 2003). Therefore, capitalist intellectual property represents the dispossession of humanity from this common wealth.

To sum up, capitalists who use information to extract surplus profits or rent-tribute combine two types of exploitation. They exploit information workers by extracting from them surplus time and fencing in the universal commons they produce. Although the workers who produce information do not produce value and surplus value, the enclosure of these commons is a necessary condition for the extraction of information surplus profit and rent-tribute from the surplus value produced by other workers. In this way, the capitalist who encloses information combines the exploitation of both types of workers. This article argues that the combination of these two types of exploitation at the global level shapes the current global division of labour, which is mediated by information technology.

\section{Conclusions: Whether Peer Production?}

Contemporary capitalism, like capitalism before, is based on the extended production of surplus value and the transformation of the overwhelming parts of this surplus value into capital (Marx 1976). This defining feature however operates through, and is expressed in, the following factors.

1. IT technology, science, innovations, knowledge and information constitute the paradigmatic productive forces of contemporary capitalism. Information plays a central role in mediating the production of relative surplus value, on the one hand, and the distribution of the total social surplus value in forms of surplus profit and rent, on the other.

2. Whether this capitalism is a new phase of monopoly capitalism that can be called "information capitalism" is an open question. However, trade secrets and intellectual property transform considerable parts of the total global surplus value produced by the global working class into technological surplus profits and information rent-tributes: transferring them to monopolists.

3. "Information capitalism" is based on a dual mechanism of exploitation. On the one hand, it exploits information workers by enclosing the universal commons of information they

\footnotetext{
${ }^{29}$ As the reader who is familiar with Fuchs' work might have realised this article disagrees with Fuchs' claim that these unpaid workers produce value and surplus value.
} 
produce and by extracting unpaid labour time from them, though this unpaid labour time does not produce surplus value. On the other hand, it exploits surplus value-producing workers by extracting profit and rent from them.

4. This dual mechanism of exploitation operates overwhelmingly, though not exclusively, through a new reconfiguration of uneven development resulting from post-1970s neoliberal globalisation. Research and development and the production of advanced technologies and services have overwhelmingly, though not exclusively, been concentrated in a handful of advanced capitalist countries. On the other hand, less advanced manufacturing and agriculture has dramatically expanded in Third World countries (Castells 2010/1996). Thus, a major portion of the total global surplus value is produced outside the territory of advanced capitalism. Advanced capitalist countries suck a significant share of this surplus value in the forms of surplus profit and rent-tribute by means of trade secrets and intellectual property (See Perlman, 2002, 2003). In this way the concomitant enclosure of information and extraction of surplus value underpin the information dimension of imperialism (see also Perelman, 2002, 2003). Hence, the hysteria of the USA and Europe against so-called Chinese and Russian industrial espionage, on the one hand, and the US and EU zeal for the protection of intellectual property, on the other.

5. "Information capitalism" and neoliberalism have mutually supported each other. The enclosure of information, which is a central aspect of contemporary capitalism, is also an instance of the neo-liberal general tendency towards enclosure (see Harvey, 2003). Furthermore, technological surplus profit and information rent-tribute have been new major levers of the further financialisation of the world economy, which is the main instrument of neo-liberal hegemony (Harvey 2010; Zeller 2008; Teixeira and Rotta 2008).

6. The description of contemporary capitalism offered here, is different from both Castells' notion of the "Network Society" (2010/1996) and Hardt and Negri's concept of "Empire" (2000), which is indeed, a radical recasting of Castells' description. The global production of surplus value, defined in a Marxian sense, remains the most essential feature of information capitalism. The particularity of information capitalism, if we can legitimately use this term, consists in the fact that the enclosure of information plays a central role in the creation of relative surplus value, on the one hand, and the distribution of the total global surplus value among the exploiting classes, on the other. Castells' and Hardt and Negri's analyses are characterized by the absence of Marx's theory of value. Hardt and Negri (2000) even claim that in so-called post-modern capitalism, which they claim is based on the exploitation of so-called bio-political labour, the very law of value is redundant.

7. That the value of information tends towards zero while information technologies constitute the vanguard forces of production of our time means that the law of value is obsolete. However, in spite of its historical redundancy this law still dominates the world economy. This domination suffocates the expansion of commons of information on the one hand and destroys nature on the other. This unprecedentedly heightened contradiction between the forces of productions (humans, information and nature) and relations of production (the law of value) is a call for abolishing of capitalism. The emerging forms of commons-promoting intellectual property, most notably the General Public License (GPL) (see Stallman 2002) and its derivatives, and the related forms of peer production (PP) that undermine both trade secrets and capitalist intellectual property offer an alternative to the capitalist mode of production (see Rigi 2013, 2014; Bauwens and Kostakis 2014; Meretz 2014; Siefkes 2012).

\section{References}

Alemling, David S. 2012. Seven Reasons Why Trade Secrets Are Increasingly Important. Barkely Technology Law Journal 27: 1098-118.

Arrighi, Giovanni. 1994. The Long Twentieth Century. New York: Verso.

Arvidsson, Adam. 2006. Brands: Meaning and Value in Media Culture. London: Routledge.

Arvidson, Adam. 2009. The Ethical Economy: Towards a Post-Capitalist Theory of Value. Capital and Class 97: 13-29. 
Arvidsson, A. and Elanor Colleoni. 2012. Value in Informtion Capitalism and on the Internet. The Information Society 28: 135-150.

Baran, Paul and Paul Sweezy. 1966. Monopoly Capital: An Essay on American Economy and Social Order. New York: Monthly Review Press.

Bauwens, Mitchel and Vasilis Kostakis. 2014. From Communism of Capital to Capital for Commons. tripleC_Cognition, Communication, Co-operation: Open Access Journal for a Global Sustainable Information Society 12 (1): 356-361. Accessed November 15, 2014. http://www.triplec.at/index.php/tripleC/article/view/564.

Blank, Rebecca, M. et al. 2012. Intellectual Property and the U.S. Economy: Industries in Perspective. U.S. Department of Commerce.

Bostol, Max and Agusti Canals. 2014. Data, Information and Knowledge. The Journal of Evolutionary Economics 14: 43-67.

Bourdieu, Pierre. 1977/1972. Outline of a Theory of Practice. Cambridge: Cambridge UP.

Boyer, Robert and Yves Saillard. 2002. Regulation Theory: State of Art. London: Routledge.

Böhm-Bawerk, E. Von. 1984. Karl Marx and Close of his System. London: Porcupine Press.

Castells, Manuel. 2010/1996. The Rise of Network Society. Oxford: Blackwell.

Caffentzis, George. 2013. In the Letters of Blood and Fire: Work, Machine and the Crisis of Capitalism. Oakland: Pm Press; Brooklyn: Common Notions.

Drab, Dave. 2003. Economic Espionage and Trade Secret Theft. Accessed October 1, 2014. http://www.Xerox.com/downloads/wpaper/x/xgs insights-espoinage.pdf.

Fine, Ben. 1979. On Marx's Theory of Agricultural Rent. Economy and Society 8: 241-278.

Foley, Duncan. 2013. Rethinking Financial Capitalism and the "information" Economy. Review of Radical Political Economics 45 (3): 257-268.

Frost, Alan. 2013/2010. Defining Knowledge, Information, Data. Accessed October 5, 2014. http://www.Knowledge-management-tools.net/knowledge-information-data.html.

Fuchs, Christian. 2009. Some Reflection on Manuel Castells' Book “Communication Power". tripleCCognition, Communication, Co-operation: Open Access Journal for a Global Sustainable Information Society 7 (1): 94-108. Accessed November 19, 2004. http://www.triplec.at/index.php/tripleC/article/view/136.

Fuchs, Christian. 2010. Labor in Information Capitalism and on the Internet. The Information Society, 26: $179-96$.

Fuchs, Christian. 2012a. With or Without Marx? With or Without Capitalism? A rejoinder to Adam Arvidson and Eleanor Colleoni. tripleC_Cognition, Communication, Co-operation: Open Access Journal for a Global Sustainable Information Society 10 (2): 633-645. Accessed September 14, 2014. http://www.triple-c.at/index.php/tripleC/article/view/434.

Fuchs, Christian. 2012b. Dallas Smythe Today-The Audience Commodity, the Digital Labour Debate. Marxist Political economy and critical Theory. Prolegomena to a Digital Labour Theory of Value. tripleC-Cognition, Communication, Co-operation: Open Access Journal for a Global Sustainable Information Society 10 (2): 692-740. Accessed September 5, 2014. http://www.triplec.at/index.php/tripleC/article/view/443.

Gallini, Nancy T. 2002. The Economics of Patents. Journal of Economic Perspectives 16 (2): 131-154.

Hardt, Michael and Antonio Negri. 1994. The Labor of Dionysus. Minneapolis: University of Minnesota Press.

Hardt, Michal and Antonio Negri. 2000. Empire. Cambridge, Mass.: Harvard UP.

Hardt, Michal and Antonio Negri. 2009. Common Wealth. Cambridge, Mass.: Harvard UP.

Hardt, Michael. 2010. The Common in Communism. In The Idea of Communism, edited by Costas Douzinas and Slavoj Zizek, 131-144. London: Verso.

Harvey, David. 1989. The Conditions of Post-Modernity. Oxford: Blackwell.

Harvey, David. 1999/1982. Limits to Capital. London: Verso.

Harvey, David. 2003. The New Imperialism. Oxford: Oxford UP.

Harvey, David. 2010. The Enigma of capital and the Crisis of Capitalism. Oxford: Oxford UP.

Harvey, David. 2013Rebel Cities: From the Right to the City to the Urban Revolution. London: Verso.

Hilferding, Rudolf. 1981/1910. Finance Capital: A study of the latest phase of capitalist development. London: Routledge and Kegan Paul.

Lenin, Vladimir I. 1963/1916. Imperialism, the Highest Stage of Capitalism. Moscow: Progress Publishers. 
Lippold, Douglas C. and Mark F. Schults. 2014. Uncovering Trade Secrets-An Empirical Assessment of Economic Implications Production from Undisclosed Data. OECD Trade Policy Proposal, No. 167. OECD Publishing. Accessed November 10, 2014. http://dx.doi.org/10.1787/5jkxz15w3j3s6-en. Mandel, Ernest. 1975/1972. Late Capitalism. London: Verso.

Mandel, Ernest. 1981. Introduction to Capital Vol. III by Karl Marx. London: Penguin Books.

Marazzi, Christian. 2010. The Violence of Financial Capital. In Crisis in the Global Capitalism: Financial Markets, Social Struggles and New Political Scenarios, edited by Andrea Fumagalli and Sandro Mazzarda, 17-59. Los Angeles: Semiotext(e).

Marx, Karl. 1966/1847. Poverty of Philosophy. Moscow: Progress Publishers.

Marx, Karl. 1978. Theories of Surplus Value, Part I. Moscow: Progress Publishers.

Marx, Karl. 1973. Grundrisse. London: Penguin Books.

Marx, Karl. 1876. Capital Vol. I. London: Penguin Books.

Marx, Karl. 1981. Capital Vol. III. London: Penguin books.

Marx, Karl. 1977. Capital Vol. I. New York: Vintage.

Meretz, Stefan. 2014. Socialist Licenses? A Rejoinder to Michel Bauwens and Vasilis Kostakis. tripleC-Cognition, Communication, Co-operation: Open Access Journal for a Global Sustainable Information Society 12 (1): 362-365. Accessed November 13, 2014. http://www.triplec.at/index.php/tripleC/article/view/564.

Negri, Atonio. 2010. Postface: A Reflection on Income in the "Great Crisis" of 2007 and Beyond. In Crisis in the Global Capitalism: Financial Markets, Social Struggles and New Political Scenarios, edited by Andrea Fumagalli and Sandro Mazzarda, 263-271. Los Angeles: Semiotext.

Passman, Pamela, et al. 2014. The Economic Impact of Trade Secret Theft.(CREATe.org). Accessed November 11, 2014. http://www.pwc./en-us/forensic-service/publications/assets/economicimpact.pdf.

Perelman, Michael. 2002. Steal this Idea: Intellectual Property Rights and Corporate Confiscation of Creativity. New York: Palgrave.

Perelman, Michael. 2003. Intellectual Property Rights and the Commodity Form: New Dimensions in Legislated Transfer of Surplus Value. Radical Political Economics, 35 (3): 304-311.

Rigi, Jakob. 2013. Peer Production and the Marxian communism: The Contours of an Emerging Mode of Production. Capital and Class 37 (3): 397-416.

Rigi, Jakob. 2014. The Coming Revolution of Peer Production and the Revolutionary Cooperatives. A Response to Michel Bauwens, Vasilis Kostakis and Stefan Meretz. tripleC - Cognition, Communication, Co-operation: Open Access Journal for a Global Sustainable Information Society 12 (1): 390-304. Accessed November 10, 2014. http://www.triple-c.at/index.php/tripleC/article/view/486.

Rigi, Jakob, and Robert Prey. Forthcoming. Value, Rent, and the Political Economy of Social Media. The Information Society.

Rigi, Jakob. n.d. The Demise of the Law of Value?!: A Critique of False Claims by Antonio Negri and his Associates.

Rosdolsky, Roman. 1977/1968. The Making of Marx Capital.Vol.1. London: Pluto Press.

Seifkes, Christian. 2012. Beyond Digital Plenty: Building Blocks for Physical Peer Production. Accessed September 15/ 2014. http://www.peerproduction.net/issues/issue-1/invitedcomments/beyond-digital-plenty/.

Smythe, Dallas. 1977. Communication: Blindspot of Western Marxism. Candian Journal of Political and Scoial Theory 1 (3):1-27.

Stallman, Richard M. 2002. Free Software, Free Society: Selected Essays of Richard M. Stallman (edited by John Gay). Boston: GNU Press.

Teixeira, R. Alves, and Tomas Nielson Rotta. 2012. Valueless Knowledge-Commodities and Financialization: Productive and Financial Dimension of Capital Autonomization. Review of Radical Political Economics. 44 (4): 1-20.

Thompson, Don. 2008. The \$12 Million Stuffed Shark: The Curious Economics of Contemporary Art. New York: Palgrave.

Vercellone, Carlo. 2010. The Crisis of the Law of Value and the Becoming Rent of Profit. In Crisis in the Global Capitalism: Financial Markets, Social Struggles and New Political Scenarios, edited by Andrea Fumagalli and Sandro Mazzarda, 86-118. Los Angeles: Semiotext.

Webster, Frank. 2006. Theories of Information Society. London: Routledge.

WIPO Intellectual Property Handbook. 2008/2004. Accessed September 12, 2014. http://www.wipo.int/sites/www/freepublications/en/intproperty/489/wipo_489.pdf. 
Zeller, Christian. 2008. From the gene to the globe: Extracting rent on the basis of intellectual property monopolies. Review of Radical Political Economic 15 (1) 86-115.

Zin, Chaim. 2007. Conceptual Approaches for Defining Data, Information and Knowledge. Journal of the American Society for Information Studies 58 (4): 479-493.

\section{About the Author}

Jakob Rigi

Jakob Rigi has a PhD from SOAS and is currently working on a Marxist theory of commons and peer production and current social movements. 